\title{
Utilizing the House Fly (Musca Domestica) Larva as an Alternative to Soybean Meal in Broiler Ration During the Starter Phase
}

\section{-Author(s)}

\section{Khan $\mathrm{M}^{\prime}$ \\ Chand $\mathrm{N}^{\prime}$ \\ Khan $\mathrm{S}^{\prime}$ \\ Khan RU \\ Sultan $A^{\prime}$}

Department of Poultry Science, Faculty of Animal Husbandry \& Veterinary Sciences, The University of Agriculture Peshawar, 25120 Pakistan

" Department of Animal Health, Faculty of Animal Husbandry \& Veterinary Sciences, The University of Agriculture Peshawar, 25120 Pakistan

\section{Mail Address}

Corresponding author e-mail address Rifat Ullah Khan

Department of Animal Health, Faculty of Animal Husbandry \& Veterinary Sciences, The University of Agriculture Peshawar, 25120 Pakistan.

Tel: $\quad$ +923157080951

Email: rifatullahkhhan@gmail.com

\section{EKeywords}

Broiler, digestibility, Maggot meal, protein, soybean meal.

\section{ABSTRACT}

A total of 120 one-day-old broiler chicks (Ross 308) were randomly assigned to 12 pens of 10 birds in a completely randomized design (CRD). In four experimental diets, soya bean meal was replaced with a maggot meal at the rate of 0,40,50 and $60 \%$ designated as group $A$, $B, C$ and $D$ respectively. Body weight was significantly higher $(p<0.05)$, whereas feed intake and feed conversion ratio (FCR) were significantly lower in group $D$ than group $A$ and $B$. Dressing percentage and apparent metabolizable energy were significantly $(p<0.05)$ higher in group $D$ than group A, B and C. Digestibility of dry matter, crude protein, ether extract and ash were significantly $(p<0.05)$ higher, and crude fiber was significantly $(p<0.05)$ lower in group $D$ than group $A$. It was concluded that $60 \%$ soybean meal could be safely replaced by a maggot meal in broiler ration during the starter phase.

\section{INTRODUCTION}

Recently, alternatives to soybean in poultry feed has attracted immense attention among the researchers and nutritionists (Tufarelli et al., 2012a; Dhama et al., 2015; Khan et al., 2016). Protein is the most expensive item in poultry production, since the same ingredients are also shared by the human and other livestock (Tufarelli et al., 2012b; Khan et al., 2016). According to Khan et al. (2010), the expenditure incurred on the purchase of feed is about $70 \%$ of the total cost of poultry operation. Therefore, to minimize the cost of feed, different feed ingredients are suggested to be substituted for soybean in poultry ration (Chand et al., 2014a). Different proportions of less expensive ingredients, which are locally available could be replaced to achieve nutritionally balanced diets (Chand et al., 2014b).

Soybean is added into the broiler ratio at very high proportions (Laudadio et al., 2012a), however, it has been reported that broiler performance could be maintained by reducing the protein level (Laudadio et al., 2012b). Recently, a number of flies and insects at different stages have been used in poultry feed (Pieterse et al., 2014; Sanchez-Muros et al., 2014). The use of larvae may be potentially hazardous and may pose a potential threat to the environment. Safety of the house fly (Musca domestica) has now been confirmed by many international bodies such as World Health Organization and the European Union for having lower levels of chemical contaminants (Charlton et al., 2015). The objective of the present study was to investigate the effects of different levels of maggot meal in broiler ration during the starter phase on performance, digestibility and taste acceptability. 


\section{MATERIALS AND METHODS}

\section{Preparation of maggot meal}

Maggot meal was prepared as described by Khan et al. (2016). After production, the maggots were killed and dried in hot air oven $\left(45^{\circ} \mathrm{C}\right)$. Dried maggots were ground in a micro mixer before use.

\section{Experimental diets and management of experimental birds}

Ration was prepared with maggot meal to replace soya bean meal at the rate of $0,40,50$ and $60 \%$ designated as $A, B, C$ and $D$ respectively (Table 1 ). A total of 120 one-day-old broiler chicks were divided into four groups and each group was divided into three replicates and randomly assigned in a completely randomized design (CRD). Feed and water were offered ad libitum. The duration of the study was of 28 days including one week of adaptation. Feed intake, body weight gain, feed conversion ratio and organ weight were observed on a weekly basis. At the end of the study, three birds per replicate were randomly selected for dressing percentage.

\section{Nutrient digestibility and chemical analysis}

On day 28, 4 birds per replicate were shifted to metabolic cages for digestibility study. Fecal material was collected for four days and feed intake was determined. Fresh feces were stored in labeled plastic bags and stored at $-20^{\circ} \mathrm{C}$. Excreta samples were analyzed for nitrogen (Kjeldahl method; AOAC, 1990), $\mathrm{CP}(\mathrm{N} \times 6.25)$, dry matter (drying in oven at $103^{\circ} \mathrm{C}$ for 8 h), crude fibre (AOAC, 1990), ether extract (AOAC, 2000) and ash (AOAC, 2000). Metabolizable energy (ME) was determined with the help of a bomb calorimeter as described by Laudadio et al. (2012b).

\section{Organoleptic study}

Organoleptic study of birds was done in the presence of faculty members and post-graduate students. Samples from different organs were cooked and used hardness scale for tenderness, juiciness, taste, color and flavor as described by Khan et al. (2017).

\section{Data collection and analysis}

Data were analyzed with analysis of variance (ANOVA) as described by Steel et al. (1997). The

Table 1 - Composition of control and experimental diets (\%)

\begin{tabular}{|c|c|c|c|c|}
\hline Ingredients & $0 \%$ & $40 \%$ & $50 \%$ & $60 \%$ \\
\hline Corn & 54.0 & 54.0 & 54.0 & 54.0 \\
\hline Broken Rice & 2.4 & 2.9 & 3.4 & 3.9 \\
\hline Cotton meal & 5.0 & 5.0 & 5.0 & 5.0 \\
\hline Guar meal & 4.0 & 4.0 & 4.0 & 4.0 \\
\hline Sunflower meal & 3.4 & 3.4 & 3.4 & 3.4 \\
\hline Soya bean meal & 10.0 & 6.0 & 5.0 & 4.0 \\
\hline Maggot meal & 0.0 & 4.0 & 5.0 & 6.0 \\
\hline Maize gluten meal (30\%) & 7.4 & 7.4 & 7.4 & 7.4 \\
\hline Fish meal (50\%) & 5.0 & 5.0 & 5.0 & 5.0 \\
\hline Rice polish & 6.0 & 6.0 & 6.0 & 6.0 \\
\hline Molasses & 1.0 & 1.0 & 1.0 & 1.0 \\
\hline Limestone & 0.4 & 0.4 & 0.4 & 0.4 \\
\hline Rock phosphate & 1.0 & 1.0 & 1.0 & 1.0 \\
\hline Lysine & 0.1 & 0.1 & 0.1 & 0.1 \\
\hline Methionine & 0.1 & 0.1 & 0.1 & 0.1 \\
\hline Vitamins minerals premix & 0.1 & 0.1 & 0.1 & 0.1 \\
\hline Salt & 0.1 & 0.1 & 0.1 & 0.1 \\
\hline \multicolumn{5}{|l|}{ Chemical analysis } \\
\hline Metabolizable energy (kcal/kg) & 2997.55 & 2989 & 2991 & 2986 \\
\hline Crude protein (\%) & 21.3 & 21.1 & 21.2 & 21.1 \\
\hline Ether extract (\%) & 4.20 & 4.18 & 4.19 & 4.17 \\
\hline Crude fiber (\%) & 3.95 & 3.91 & 3.93 & 3.91 \\
\hline Ash (\%) & 5.48 & 5.42 & 5.44 & 5.45 \\
\hline Calcium (ppm) & 0.77 & 0.76 & 0.77 & 0.79 \\
\hline Phosphorus (ppm) & 0.31 & 0.29 & 0.30 & 0.31 \\
\hline Lysine ( $\%$ of Total amino acids) & 1.36 & 1.36 & 1.37 & 1.38 \\
\hline Methionine (\% of Total amino acids) & 0.46 & 0.52 & 0.58 & 0.64 \\
\hline Cysteine (\% of Total amino acids) & 0.34 & 0.34 & 0.33 & 0.33 \\
\hline
\end{tabular}


Table 2 - Feed intake ( $\mathrm{g}$ ) of control and experimental broilers

\begin{tabular}{lccccc}
\hline S.NO & WEEK I & WEEK II & WEEK III & WEEK IV & Overall mean \\
\hline A & $246.44^{\mathrm{a}} \pm 1.55$ & $467.44^{\mathrm{a}} \pm 1.78$ & $950.15^{\mathrm{a}} \pm 2.91$ & $961.63^{\mathrm{a}} \pm 0.99$ & $2649.54^{\mathrm{a}} \pm 2.51$ \\
B & $241.19^{\mathrm{ab}} \pm 2.59$ & $458.55^{\mathrm{c}} \pm 1.15$ & $858.58^{\mathrm{b}} \pm 5.90$ & $951.20^{\mathrm{c}} \pm 0.74$ & $2509.52^{\mathrm{b}} \pm 3.21$ \\
C & $238.10^{\mathrm{b}} \pm 1.30$ & $452.90^{\mathrm{b}} \pm 1.15$ & $858.63^{\mathrm{b}} \pm 5.59$ & $932.61^{\mathrm{b}} \pm 2.31$ & $2482.244^{\mathrm{c}} \pm 1.19$ \\
D & $219.59^{\mathrm{c}} \pm 3.34$ & $494.27^{\mathrm{d}} \pm 2.30$ & $827.75^{\mathrm{c}} \pm 3.46$ & $958.68^{\mathrm{c}} \pm 2.84$ & $2476.41^{\mathrm{c}} \pm 2.00$ \\
\hline
\end{tabular}

Different superscripts in a column differ significantly $(p<0.05)$

$A=$ control group $B=$ group having $40 \%$ maggot meal replacement $C=$ group, $50 \%$ maggot meal replacement $D=$ group having $60 \%$ maggot meal replacement

Table 3 - Weekly body weight (g) of control and experimental broiler

\begin{tabular}{lccccc}
\hline S NO & Week I & Week II & Week III & Week IV & Overall mean \\
\hline A & $183.44^{\mathrm{c}} \pm 1.78$ & $177.52^{\mathrm{c}} \pm 4.02$ & $405.00^{\mathrm{c}} \pm 2.89$ & $409.89^{\mathrm{b}} \pm 3.17$ & $1175.85^{\mathrm{c}} \pm 3.08$ \\
B & $183.44^{\mathrm{c}} \pm 1.73$ & $210.24^{\mathrm{b}} \pm 1.70$ & $419.77^{\mathrm{b}} \pm 2.24$ & $427.27^{\mathrm{a}} \pm 2.21$ & $1240.72^{\mathrm{b}} \pm 1.90$ \\
C & $188.66^{\mathrm{ab}} \pm 1.16$ & $217.08^{\mathrm{ab}} \pm 2.29$ & $419.77^{\mathrm{b}} \pm 2.17$ & $428.58^{\mathrm{a}} \pm 1.73$ & $1254.09^{\mathrm{b}} \pm 1.99$ \\
D & $192.21^{\mathrm{a}} \pm 1.67$ & $220.04^{\mathrm{a}} \pm 1.20$ & $441.21^{\mathrm{a}} \pm 2.39$ & $434.39^{\mathrm{a}} \pm 1.14$ & $1287.85^{\mathrm{a}} \pm 1.58$ \\
\hline
\end{tabular}

Different superscripts in a column differ significantly $(p<0.05)$

$A=$ control group $B=$ group having $40 \%$ maggot meal replacement $C=$ group, $50 \%$ maggot meal replacement $D=$ group having $60 \%$ maggot meal replacement

Table 4 - Feed conversion ratio of control and experimental broiler

\begin{tabular}{lccccc}
\hline S NO & Week I & Week II & Week III & Week IV & Overall mean \\
\hline A & $1.34^{\mathrm{a}}$ & $2.32^{\mathrm{a}}$ & $2.34^{\mathrm{a}}$ & 2.33 & $2.08^{\mathrm{a}}$ \\
B & $1.31^{\mathrm{a}}$ & $2.18^{\mathrm{b}}$ & $2.04^{\mathrm{b}}$ & 2.22 & $1.93^{\mathrm{b}}$ \\
C & $1.26^{\mathrm{b}}$ & $2.08^{\mathrm{b}}$ & $2.03^{\mathrm{b}}$ & 2.17 & $1.88^{\mathrm{b}}$ \\
D & $1.14^{\mathrm{c}}$ & $2.12^{\mathrm{b}}$ & $1.87^{\mathrm{c}}$ & 1.85 & $1.74^{\mathrm{c}}$ \\
\hline
\end{tabular}

Different superscripts in a column differ significantly $(p<0.05)$

$A=$ control group $B=$ group having $40 \%$ maggot meal replacement $C=$ group, $50 \%$ maggot meal replacement $D=$ group having $60 \%$ maggot meal replacement

Duncan Multiple Range test was used (Duncan, 1955) for significance. P values less than 0.05 were considered statistically significant.

\section{RESULTS}

Significantly the highest $(p<0.05)$ feed intake was observed in group A having no replacement of maggot meal, while the lowest $(p<0.05)$ feed intake was observed in group D having 60\% replacement of maggot meal. Birds in groups $C$ and $D$ also had significantly $(p<0.05)$ lower intake than group B (Table 2 ). The decreasing trend of feed intake with increasing replacement may be due to high protein and fats in maggot meal as compared to soya bean meal.

Significant effect on body weight was observed in treated groups as compared to the control (Table 3). However, the effect within the treated groups was not significant. Group D provided with $60 \%$ soya bean meal replacement resulted in a higher body weight gain. The increase in body weight of birds with maggot meal containing feed may be due to rich lipid contents of maggot meal.

Overall FCR was significantly $(p<0.05)$ affected by replacing soybean meal with maggot meal. The highest (poor) FCR was recorded for group A, while the lowest FCR was recorded for group D. There was no significant difference between the FCR of groups $B$ and $C$. This indicated the efficient utilization of experimental ration with maggot meal replacement.

The significant effect of maggot meal replacement on dressing percentage of the chicks was observed (Table 5). The mean value of dressing percentage for D group was higher, while the lowest was calculated for the control group. The increasing trend of dressing percentage was associated with the increasing use of maggot meal in the ration.

Table 5 - Dressing percentage and apparent metabolizable energy of experimental chicks

\begin{tabular}{ccc}
\hline S.No & Dressing percentage (\%) & $\begin{array}{c}\text { Apparent metabolisable energy } \\
(\text { Kcal } / \mathrm{kg})\end{array}$ \\
\hline A & $55.09^{\mathrm{c}} \pm 0.51$ & $12.70^{\mathrm{c}} \pm 0.03$ \\
\hline B & $57.26^{\mathrm{b}} \pm 0.18$ & $12.96^{\mathrm{b}} \pm 0.01$ \\
\hline C & $57.53^{\mathrm{b}} \pm 0.27$ & $13.03^{\mathrm{b}} \pm 0.09$ \\
\hline D & $59.98^{\mathrm{a}} \pm 0.22$ & $13.16^{\mathrm{a}} \pm 0.09$ \\
\hline
\end{tabular}

Different superscripts in a column differ significantly $(p<0.05)$

$A=$ control group $B=$ group having $40 \%$ maggot meal replacement $C=$ group, $50 \%$ maggot meal replacement $\mathrm{D}=$ group having $60 \%$ maggot meal replacement

The effect of maggot meal on AME was calculated better for groups offered with high percentage of maggot meal. The better utilization of energy in these birds is also observed on the performance of chicks. 
Table 6 - Digestibility of nutrients of control and experimental broiler

\begin{tabular}{lccccc}
\hline S NO & Dry matter (\%) & Crude protein (\%) & Crude fiber (\%) & Ether extract (\%) & Ash (\%) \\
\hline A & $81.81^{\mathrm{b}} \pm 0.24$ & $81.58^{\mathrm{b}} \pm 0.04$ & $85.89^{\mathrm{b}} \pm 0.03$ & $70.91^{\mathrm{b}} \pm 0.40$ & $38.70^{\mathrm{b}} \pm 0.67$ \\
B & $82.22^{\mathrm{ab}} \pm 0.19$ & $81.86^{\mathrm{a}} \pm 0.11$ & $85.67^{\mathrm{ab}} \pm 0.12$ & $72.86^{\mathrm{ab}} \pm 0.20$ & $46.38^{\mathrm{b}} \pm 1.69$ \\
C & $82.25^{\mathrm{ab}} \pm 0.25$ & $82.30^{\mathrm{ab}} \pm 0.08$ & $85.61^{\mathrm{ab}} \pm 0.32$ & $72.84^{\mathrm{ab}} \pm 1.70$ & $49.81^{\mathrm{bc}} \pm 0.79$ \\
D & $82.85^{\mathrm{a}} \pm 0.10$ & $82.90^{\mathrm{a}} \pm 0.43$ & $84.96^{\mathrm{a}} \pm 0.76$ & $74.96^{\mathrm{a}} \pm 0.91$ & $50.29^{\mathrm{a}+ \pm} 0.71$ \\
\hline
\end{tabular}

Different superscripts in a column differ significantly $(p<0.05)$

$A=$ control group $B=$ group having $40 \%$ maggot meal replacement $C=$ group, $50 \%$ maggot meal replacement $D=$ group having $60 \%$ maggot meal replacement

Table 7 - Organoleptic study of broiler meat fed with different level of maggot meal

\begin{tabular}{lccccc}
\hline Group & Taste & Tenderness & Juiciness & Color & Flavor \\
\hline A & $2.40 \pm 0.20$ & $2.16 \pm 0.17$ & $2.46 \pm 0.27$ & $2.56 \pm 0.21$ & $2.30 \pm 0.17$ \\
\hline B & $2.40 \pm 0.37$ & $2.14 \pm 0.30$ & $2.43 \pm 0.20$ & $2.55 \pm 0.41$ & $2.28 \pm 0.25$ \\
\hline C & $2.33 \pm 0.26$ & $2.12 \pm 0.15$ & $2.44 \pm 0.20$ & $2.56 \pm 0.12$ & $2.30 \pm 0.20$ \\
\hline D & $2.36 \pm 0.06$ & $2.13 \pm 0.00$ & $2.47 \pm 0.06$ & $2.54 \pm 0.06$ & $2.29 \pm 0.10$ \\
\hline
\end{tabular}

$A=$ control group $B=$ group having $40 \%$ maggot meal replacement $C=$ group, $50 \%$ maggot meal replacement $D=$ group having $60 \%$ maggot meal replacement

Digestibility of dry matter, crude protein, crude fiber and ether extract was higher $(p<0.05)$ for group $D$ as compared to the control group. Within treated groups the differences were non-significant $(p>0.05)$ for dry matter, crude fiber and ether extract. Within treated groups higher digestibility of crude protein and ash was recorded for group $D$.

A non-significant effect of maggot meal replacement on taste, tenderness, juiciness, colour and flavour was observed.

\section{DISCUSSION}

Significantly higher feed intake was observed in the group having no replacement of maggot meal, while the lowest feed intake was observed in birds having $60 \%$ replacement of maggot meal. The findings of the present study are in the line with results of Khan et al. (2016) who concluded that feed intake was decreased in the group offered with maggot meal in the ration. Similarly, Okah \& Onwujiariri (2012) concluded that feed intake by birds reduced significantly with the increasing maggot meal substitution in the ration. The lower feed intake may be due to high lipid contents in maggot meal (15\%) as compared to soya bean meal (1.0\%). The lower intake with high lipid contents has also been reported by Poorghasemi et al. (2013). More digestible protein and rich in amino acid such as lysine (6.04 \%) and methionine (2.28) in maggot meal as compared to soya bean meal could also be the reason for lower intake in groups provided with maggot meal.

Maggot meal positively affected the body weight gain. Significantly higher body weight gain was observed for the group having higher replacement of maggot meal. The finding of the current study is in line with the results of Poorghasemi et al. (2013). Similarly, Khan et al. (2016) and Okah and Onwujiariri (2012) also reported significantly higher $(p<0.05)$ weight gain for the birds offered with ration having maggot meal inclusion. The increased body weight gain may be due to the high amino acid, minerals and lipid profile of maggot meal. The lipids act as sparer for protein and could be used to maximize protein utilization for growth of animals (Jauncey \& Ross, 1982).

The FCR was significantly lower $(p>0.05)$ for birds having maggot meal substitution. The present findings are in line with the study of Okah \& Onwujiariri (2012). They observed that the birds offered maggot meal in their ration resulted in significantly lower feed conversion ratio as compared to the control group. Similarly, Moreki et al. (2012) used insects as protein source in broiler diet and recorded better feed conversion ratio for treated groups. Khan et al. (2016) also reported lower feed intake and FCR.

In the current study, replacement of soya bean meal with maggot meal showed significant effect on dressing percentage. The findings of this study are in line with the results of Khan et al. (2016). They observed that maggot meal significantly improved dressing percentage and carcass weight. Similarly Hwangbo et al. (2008) concluded that offering maggot meal in the ration significantly enhances thigh muscle, breast muscle and carcass weight of the birds. High crude protein, lipids and essential amino acid may be a reason for the higher dressed weight of birds provided with maggot meal.

In the present study, apparent metabolisable energy was significantly higher for birds fed with a maggot 
meal in their ration. The findings of the current study are inconsistent with the results of Harinder et al. (2014) who reported that apparent metabolisable energy was higher fed insect meal. Similarly, Khan et al. (2016) also recorded higher apparent metabolisable energy for birds fed with maggot meal. This high apparent metabolisable energy is due to the high fat contents present in maggot meal. Fat possess a lot of energy which is released when fat is oxidized (Adeniji, 2007). Nutrient digestibility of dry matter, crude protein, crude fiber, ether extract and ash was observed significantly for group having $60 \%$ maggot meal as compared to the control group. The results of the present study is in line with the study of Hwangbo et al. (2009) who found that digestibility of dry matter, crude protein, etc. was higher as compared to the control group. The increased digestibility may be due to the high fat content in the maggot meal which enhances the digestibility of protein.

Maggot meal replacement with soya bean meal had no effect on taste, tenderness, juiciness, color and flavor in the present study. Current results are in line with the findings of Khan et al. (2016) who concluded that maggot meal has no effect on taste, tenderness, juiciness, and flavor. This indicated that maggot meal is tasteless, colorless and odorless and birds take it indiscriminately as an ordinary source of protein.

\section{CONCLUSION}

It was concluded that $60 \%$ soybean meal could be safely and profitably replaced by a maggot meal in broiler ration during early days of production

\section{ACKNOWLEDGMENTS}

This study was financially supported by Pakistan Science Foundation through project number PSF/ NLSP/KP-AU(293).

\section{REFERENCE}

AOAC. Official methods of analysis. 15 $5^{\text {th }}$ ed. Washington: Association of Official Analytical Chemists; 1990.

AOAC. Official methods of analysis. $17^{\text {th }}$ ed. Arlington: Association of Official Analytical Chemists; 2000.

Adeniji AA. Effect of replacing groundnut cake with maggot meal in the diet of broilers. International Journal of Poultry Science 2007;6(11):822825 .

Chand NI, Khan RU. Replacement of soybean meal with yeast single cell protein in broiler ration:the effect on performance traits. Pakistan Journal of Zoology 2014a;46(6):1753-1758.
Chand N, Naz S, Shah Z, Khan S, Shah AS, Khan RU. Growth performance and immune status of broilers fed graded levels of Albizia lebbeck seeds. Pakistan Journal of Zoology 2014b;46(2):574-577.

Charlton AJ, Dickinson M, Wakefield ME, Fitches E, Kenis M, Han R, et al. Exploring the chemical safety of fly larvae as a source of protein for animal feed. Journal of Insects as Food and Feed 2015;1:7-16.

Dhama K, Latheef SK, Mani S, Samad A, Karthik H, Tiwari K, et al. Multiple beneficial applications and modes of action of herbs in poultry health and production. International Journal of Pharmacology 2015;11:152176

Duncan DB. Multiple range and multiple F-Tests. Biometrics 1955;11:1-42.

Harinder PSM, Gilles T, Henze V, Ankers P. Stats of the art on use of insects as animal feed. Animal Feed Science 2014;197:1-33.

Hwangbo J, Hong EC, Jang A, Kang HK, Oh, JS, Kim BW, et al. Utilization of house fly-maggots, a feed supplement in the production of broiler chickens. Journal of Environmental Biology 2008;30:609-614.

Hwangbo J, Hong EC, Jang A, Kang HK, Oh JS, Kim BW, et al. Utilization of house fly-maggots, a feed supplement in the production of broiler chickens. Journal of Environmental Biology 2009;30:609-614.

Jauncey K, Ross B. A guide to tilapia feeds and feeding. Stirling: Institute of Aquaculture, University of Stirling; 1982. 111p.

Khan RU, Durrani FR, Chand N. Influence of feed supplementation with Cannabis sativa on quality of broilers carcass. Pakistan Veterinary Journal 2010;30:34-38.

Khan S, Khan RU, Sultan A, Khan M, Hayat SU, Shahid MS. Evaluating the suitability of maggot meal as a partial substitute of soya bean on the productive traits, digestibility indices and organoleptic properties of broiler meat. Journal of Animal Physiology and Animal Nutrition 2016;100:649-656.

Khan S, Khan RU, Alam W, Sultan A. Evaluating the nutritive profile of three insects meal and their effect to replace soybean in broiler diet. Journa of Animal Physiology and Animal Nutrition. In press 2017

Mahmood K, Malik KA, Lodhi MAK, Sheikh KH. Seed germination and salinity tolerance in plant species growing on saline wastelands. Biologia Plantarum 1996;38:309-315.

Laudadio V, Passantino L, Perillo A, Lopresti G, Passantino A, Khan RU, et al. Productive performance and histological features of intestinal mucosa of broiler chickens fed different dietary protein levels. Poultry Science 2012a;91(1):265-270.

Laudadio V, Dambrosio A, Normanno G, Khan RU, Naz S, Rowghani E, et al. Effect of reducing dietary protein level on performance responses and some microbiological aspects of broiler chickens under summer environmental conditions. Avian Biology Research 2012b;5(2):88-92.

Moreki JC, Tiroesele B, Chiripasi, S.C. Prospects of utilizing insects as alternative sources of protein in poultry diets in botswana: a review. Journal of Animal Science Advance 2012;2(8):649-658.

Okah U, Onwujiariri EB. Performance of finisher broiler chickens fed maggot meal as a replacement for fish meal. Journal of Agriculture Technology 2012;8(2):471-477.

Pieterse E, Pretorius Q, Hoffman LC, Drew DW. The carcass quality, meat quality and sensory characteristics of broilers raised on diets containing either Musca domestica larvae meal, fish meal or soya bean meal as the main pro tein source. Animal Production Science 2014;54:622-628.

Poorghasemi M, Seidavi A, Qotbi AA, Laudadio V, Tufarelli V. Influence of dietary fat source on growth performance responses and carcass traits of broiler chicks. Asian-Australasian Journal Animal Science 2013;26(5):705-710. 
Sanchez-Muros M, Barroso FG, Manzano-Agugliaro F. Insect meal as renewable source of food for animal feeding:a review. Journal of Cleaner Production 2014;65:16-27.

Steel RGD, Torrie JH, Diekey DA. Principles and procedures statistics: a biometrical approach. New York: Graw Hill Book; 1997.

Tufarelli V, Khan RU, Laudadio V. Evaluating the suitability of field beans as a substitute for soybean meal in early-lactating dairy cows: production and metabolic responses. Animal Science Journal 2012a;83:136-140.

Tufarelli V, Naz S, Khan RU, Mazzei D, Introna M, Laudadio V. Milk quality, manufacturing properties and blood biochemical profile from dairy cows fed peas (Pisum sativum L.) as dietary protein supplement. Archiv Tierzucht 2012b;55(2):132-139. 